\title{
Comparison of Multiplex Real-Time Polymerase Chain Reaction Assays for Detection of Respiratory Viruses in Nasopharyngeal Specimens
}

\author{
Jean Damascene Uwizeyimana ${ }^{1,2,3}$, Min Kyung Kim ${ }^{1}$, \\ Daewon Kim ${ }^{1}$, Jung-Hyun Byun ${ }^{1}$, Dongeun Yong ${ }^{1}$ \\ ${ }^{1}$ Department of Laboratory Medicine and Research Institute of Bacterial Resistance, Yonsei University College \\ of Medicine, ${ }^{2}$ Department of Global Health Security, Yonsei University Graduate of Public Health, Seoul, Korea, \\ ${ }^{3}$ Department of Emergency Care, Ruli Hospital, Gakenye, Rwanda
}

Background: Respiratory tract infections are major public health threats, and the identification of their causative microbes helps clinicians to initiate timely and appropriate antimicrobial therapy and prevent the secondary spread of infection. The main goal of this study was to compare two multiplex real-time polymerase chain reaction (PCR) assays used to detect respiratory viral pathogens in nasopharyngeal swab specimens.

Methods: Between September and October 2017, a total of 84 nasopharyngeal specimens were obtained consecutively from patients in a tertiary hospital using a flocked swab with $3 \mathrm{~mL}$ universal transport medium (COPAN Diagnostics, USA). A total of 64 positive and 20 negative sample results from the LG Advansure RV real-time RT-PCR kit (LG Life Sciences, Korea) were further retested using a new AdvanSure RV-plus a real-time RT-PCR kit to compare their performance.

Results: Statistical analysis of positive and negative agreement between the two different kits was conducted between the newly introduced AdvanSure
RV-plus real-time RT-PCR kit and the AdvanSure RV real-time RT-PCR. The overall agreement was $96.4 \%$, with positive agreement of $98.4 \%$ and negative agreement of $90 \%$. The evaluated sensitivity and specificity of AdvanSure RV-plus real-time RT-PCR were $96.9 \%$ and $94.7 \%$, respectively, with a kappa value of $0.9(P<0.001)$.

Conclusion: The performances of LG AdvanSure RV real-time RT-PCR and the new AdvanSure RV-plus real-time RT-PCR kit showed strong overall agreement. AdvanSure RV-plus real-time RT-PCR had a better detection rate and could detect coronavirus 229E and enterovirus, especially with a high detection rate in coinfection. AdvanSure RV-plus real-time RT-PCR can be considered a useful tool for respiratory virus diagnosis in clinical laboratories. (Ann Clin Microbiol 2019;22:35-41)

Key Words: Diagnosis, Multiplex polymerase chain reaction, Pneumonia, Real-time polymerase chain reaction, Virus

\section{INTRODUCTION}

Morbidity and mortality from viral respiratory tract infections are major public health threats [1,2]. Approximately one-half of acute respiratory infections are due to viruses. Acute respiratory infections reduce economic productivity and incur a great cost for medical health care services. Despite the introduction of anti-viral medications and vaccines during the $20^{\text {th }}$ century, it is still challenging to identify specific interventions for proper management of respiratory viruses (RV) $[1,3,4]$. Each year Asia and Africa experience about 134 and 131 million cases of lower respiratory tract infections, respectively, and overall, 429 million respiratory tract infections are experienced globally across all ages [5]. The identification of causative microbes helps clinicians to initiate timely and appropriate antimicrobial-therapy, prevent the use of unnecessary antibiotics, and avoid secondary

Received 28 September, 2018, Revised 25 February, 2019, Accepted 26 February, 2019

Correspondence: Dongeun Yong, Department of Laboratory Medicine, Yonsei University College of Medicine, 50-1 Yonsei-ro, Seodaemun-gu, Seoul 03722, Korea. (Tel) 82-2-2228-2442, (Fax) 82-2-364-1583, (E-mail) deyong@yuhs.ac

(c) The Korean Society of Clinical Microbiology.

(․) This is an Open Access article distributed under the terms of the Creative Commons Attribution Non-Commercial License (http://creativecommons.org/licenses/by-nc/4.0) which permits unrestricted non-commercial use, distribution, and reproduction in any medium, provided the original work is properly cited. 
spread of infection [6].

Traditionally, viral diagnostic cell culture is considered the gold standard, but this process requires 10 to 14 days [7]. Due to the need for rapid and accurate diagnosis, priority is given to viral diagnostic tools that give immediate results. The viral culture technique has limited utility for clinicians, as the results are obtained too late for effective clinical management decisions [8]. Viral management outcomes depend on rapid diagnosis, sensitivity, and specificity to ensure proper detection of viral pathogens, effective anti-viral therapy, and preventive strategies [9-11]. It is almost impossible to differentiate bacterial and viral respiratory tract infections by clinical signs and symptoms, radiology, or biochemical markers, which leads to inappropriate use of antibiotics [12]. Multiplex PCR is a validated tool for early respiratory pathogen detection with high diagnostic accuracy [13]. Nasal smear cultures were reported as less reliable for detection of the etiologies of pneumonia. To maximize clinical diagnosis and effectiveness, real-time PCR is considered a well-established methodology for the detection, quantification, and typing of different microbial pathogens in clinical diagnosis $[12,14,15]$. Nasopharyngeal specimens are usually considered the best type of specimen for early detection of RV [16]. AdvanSure RV real-time RT-PCR (LG Life Sciences, Seoul, Korea) has been widely used in clinical practice and can detect 14 viruses using five tubes. AdvanSure RV real-time RT-PCR (LG Life Sciences) has demonstrated capacity for diagnosing RV with acceptable specificity and sensitivity. A newly introduced RV kit, AdvanSure RV-plus real-time RT-PCR (LG Life Sciences), can detect $15 \mathrm{RV}$ and uses four tubes to reduce laboratory work load and hands-on time. Comprehensive evaluation of the new AdvanSure RV-plus real-time RT-PCR kit (LG Life Sciences) is required for laboratory physicians to decide on the best methods for RV diagnosis.

The aim of this study is to compare and evaluate the performance of the AdvanSure RV-plus real-time RT-PCR kit (LG Life Sciences), a multiplex real-time polymerase chain reaction-based kit, to that of LG AdvanSure RV real-time RT-PCR (LG Life Sciences).

\section{MATERIALS AND METHODS}

\section{Subjects}

Between September to October 2017, 84 nasopharyngeal specimens were consecutively obtained from patients in a tertiary care hospital using flocked swabs and $3 \mathrm{~mL}$ universal transport medium (COPAN Diagnostics, Murrieta, CA, USA). Specimens were stored at $-70^{\circ} \mathrm{C}$. There were 64 positive sample results and 20 negative sample results from the LG AdvanSure RV real-time RT-PCR kit (LG Life Sciences), which was adopted in the laboratory. Samples were further tested by AdvanSure RV-plus real-time RT-PCR (LG Life Sciences) to compare with the results of LG AdvanSure RV real-time RT-PCR (LG Life Sciences) and to evaluate the performance of the new AdvanSure RV-plus real-time RT-PCR kit (LG Life Sciences). A positive result from all two methods or from AdvanSure RV-plus real-time RT-PCR (LG Life Sciences) or from AdvanSure RV real-time RT-PCR (LG Life Sciences) was considered to be a true positive in this study [17]. The Research Ethics Board approved this study (Approval No. 4-2016-1029).

\section{Nucleic acid extraction and multiplex real-time PCR assays}

The RNA and DNA extraction process consisted of several steps according to the manufacturer's instructions. Briefly, 200 $\mu \mathrm{L}$ of nasopharyngeal specimen was used with TANBead automated magnetic bead operating platform using Smart LabAssist-32 and Tanbead Optipure Nucleic Acid (Taiwan Advanced Nanotech Inc. Taoyuan City, Taiwan) [17]. AdvanSure RV real-time PCR kits, AdvanSure Nucleic Acid R kits, and AdvanSure RV-plus real-time RT-PCR kits (LG Life Sciences) were used to detect respiratory viruses, including RNA and DNA viruses. Then, $5 \mu \mathrm{L}$ of extracted nucleic acid was mixed with $5 \mu \mathrm{L}$ of primer probe to result in $10 \mu \mathrm{L}$ used for one-step operating cDNA synthesis and real-time polymerase chain reaction. The next step for reverse transcriptase consisted of incubating the mixture following the manufacturer's instructions. To prevent misjudgment sample error and real time PCR error, the internal control of endogenous RNase polymerase was used to validate the RNA extraction procedure.

\section{Statistical analysis}

A total of 84 clinical nasopharyngeal samples including 64 samples with positive results and 20 samples with negative results using the old LG AdvanSure RV real-time RT-PCR kit (LG Life Sciences) were further tested by AdvanSure RV-plus real-time RT-PCR (LG Life Sciences). Overall agreement, sensitivity, specificity, kappa, and $P$ values were analyzed. All statistical and data analyses were done by SPSS (Version 21.0. Armonk, NY, USA). A $P$ value $\leq 0.05$ was considered significant. 


\section{RESULTS}

Eighty-four nasopharyngeal respiratory samples were tested using two kits, and 12 respiratory viral pathogens including Adenovirus (Adeno); Bocavirus (BoV); Respiratory syncytial virus A and B (RSVA, RSVB); Rhinovirus (Rhino); Metapneumovirus (MPV); Parainfluenza Virus 1 and 3 (PIV1, PIV3); Influenza virus A (INFA); coronavirus E229 (E229); Enterovirus (ENT); coronavirus OC43 (OC43) were detected. The statistical analysis of positive and negative agreement between the two different kits, the newly introduced AdvanSure RV-plus real-time RT-PCR kit (LG Life Sciences) and the AdvanSure RV real-time PCR RT-PCR kit (LG Life Sciences), was performed. Overall agreement was $96.4 \%$, positive agreement was $98.4 \%$, and negative agreement was $90.0 \%$ (data not shown). The sensitivity and specificity of AdvanSure RV-plus real-time RT-PCR (LG Life Sciences) were evaluated. The specificity was $94.7 \%$ and the sensitivity was $96.9 \%$ with kappa of 0.9 .

The AdvanSure RV-plus real-time RT-PCR (LG Life Sciences) could detect 229E which was missed by the AdvanSure RV real-time RT-PCR (LG Life Sciences) and additionally detect ENT (Table 1). AdvanSure RV-plus real-time

Table 1. Overall sensitivity comparison table

\begin{tabular}{lrrrr}
\hline & \multicolumn{4}{c}{ No. (\%) of positives } \\
\cline { 2 - 5 } Target \\
virus & $\begin{array}{c}\text { Total true } \\
\text { positive }\end{array}$ & $\begin{array}{c}\text { AdvanSure } \\
\text { RV-plus real-time } \\
\text { RT-PCR }\end{array}$ & $\begin{array}{c}\text { AdvanSure } \\
\text { RV real-time } \\
\text { RT-PCR }\end{array}$ & $\begin{array}{c}\text { Statistical } \\
\text { difference }\end{array}$ \\
\hline Adeno & 11 & $11(100)$ & $10(90.9)$ & NS \\
$229 E$ & 2 & $2(100)$ & - & - \\
BoV & 11 & $11(100)$ & $10(90.9)$ & NS \\
ENT & 5 & $5(100)$ & - & - \\
INFA & 7 & $7(100)$ & $7(100)$ & NS \\
MPV & 9 & $9(100)$ & $8(88.9)$ & NS \\
OC43 & 7 & $6(85.7)$ & $7(100)$ & NS \\
PIV1 & 2 & $2(100)$ & $2(100)$ & NS \\
PIV3 & 9 & $9(100)$ & $9(100)$ & NS \\
Rhino & 16 & $16(100)$ & $15(93.8)$ & NS \\
RSVA & 7 & $7(100)$ & $6(85.7)$ & NS \\
RSVB & 1 & $1(100)$ & $1(100)$ & NS \\
Total & 87 & $86(98.9)$ & $75(86.2)$ & $<0.001$ \\
\hline
\end{tabular}

Abbreviations: RT-PCR, real-time polymerase chain reaction; Adeno, adenovirus; 229E, coronavirus; BoV, bocavirus; ENT, enterovirus; INFA, inflenza virus A; MPV, metapneumovirus; OC43, coronavirus OC43; PIV1 and PIV3, parainflenza virus 1 and 3; Rhino, rhinovirus; RSVA and RSVB, respiratory syncytial virus A and B; NS, not significant.
RT-PCR (LG Life Sciences) showed a higher detection rate for six viruses. Detection rates of adenovirus were $90.9 \%(n=10)$ with AdvanSure RV real-time RT-PCR (LG Life Sciences) and 100\% ( $\mathrm{n}=11$ ) with AdvanSure RV-plus real-time RT-PCR (LG Life Sciences). The detection rate of MPV with AdvanSure RV-plus real-time RT-PCR (LG Life Sciences) was 100\% $(\mathrm{n}=9)$, while with AdvanSure RV real-time RT-PCR (LG Life Sciences) was $88.9 \%(n=8)$. Detection of rhinovirus was 93.8 $(\mathrm{n}=15)$ for AdvanSure RV real-time RT-PCR (LG Life Sciences) and 100\% $(n=16)$ for AdvanSure RV-plus real-time RT-PCR (LG Life Sciences); detection of RSVA was $85.7 \%$ $(\mathrm{n}=6)$ for AdvanSure RV real-time RT-PCR (LG Life Sciences) and $100 \%(\mathrm{n}=7)$ for AdvanSure RV-plus real-time RT-PCR (LG Life Sciences); the detection rate for OC43 was $85.7 \%(n=6)$ for AdvanSure RV-plus real-time RT-PCR (LG Life Sciences) and $100 \%(n=7)$ for AdvanSure RV real-time RT-PCR (LG Life Sciences). BoV was detection percentage was $90.9 \%(n=10)$ for AdvanSure RV real-time RT-PCR (LG Life Sciences) and $100 \%(\mathrm{n}=11)$ for AdvanSure RV-plus real-time RT-PCR (LG Life Sciences). Similar detection rates were found in the following viruses: INFA, PIV1, PIV3, and RSVB. In summary, the RV real-time PCR RT-PCR (LG Life Sciences) detected 75 (86.2\%) positive results, while AdvanSure RV-plus real-time RT-PCR (LG Life Sciences) detected 86 (98.9\%) positive results. AdvanSure RV-plus real-time RT-PCR (LG Life Sciences) showed good performance in specimens infected with multiple viruses (Table 2). AdvanSure RV-plus real-time RT-PCR (LG Life Sciences) detected 42.5\% $(n=37)$ in 16 co-infected clinical samples, while AdvanSure RV real-time RT-PCR (LG Life Sciences) detected $21.8 \%(n=19)$ in 9 clinical samples with co-infection with multiple viruses. 16 co-infected clinical samples detected by AdvanSure RV-plus real-time RT-PCR (LG Life Sciences), 6 of them were the same for both two kits and 10 samples showed different virus (Table 3 ), and detection rates increased in new test kits when samples have coinfection with enterovirus and coronavirus.

\section{DISCUSSION}

Acute respiratory tract infections due to respiratory viruses present with similar clinical features as respiratory infections due to bacteria [12]. Delayed diagnostic results may result in physicians initiating antibiotic therapy without etiological identification results [18]. Inappropriate antibiotic use for management of respiratory viral infections is prevalent worldwide and 
Table 2. Distribution of RVs in clinical nasopharyngeal specimens by AdvanSure RV real-time RT-PCR and AdvanSure RV-plus real-time RT-PCR

\begin{tabular}{|c|c|c|c|c|c|c|c|c|c|}
\hline \multirow{3}{*}{$\begin{array}{c}\text { Target } \\
\text { viruses }\end{array}$} & \multirow{3}{*}{$\begin{array}{l}\text { No. of } \\
\text { true } \\
\text { positive }\end{array}$} & \multicolumn{8}{|c|}{ No. $(\%)$ of positive } \\
\hline & & \multicolumn{2}{|c|}{ Overall } & \multicolumn{2}{|c|}{ Single virus } & \multicolumn{2}{|c|}{ Two viruses } & \multicolumn{2}{|c|}{ Three viruses } \\
\hline & & $\begin{array}{l}\text { AdvanSure } \\
\text { RV-plus } \\
\text { real-time } \\
\text { RT-PCR }\end{array}$ & $\begin{array}{l}\text { AdvanSure } \\
\text { RV real-time } \\
\text { RT-PCR }\end{array}$ & $\begin{array}{l}\text { AdvanSure } \\
\text { RV-plus } \\
\text { real-time } \\
\text { RT-PCR }\end{array}$ & $\begin{array}{l}\text { AdvanSure } \\
\text { RV real-time } \\
\text { RT-PCR }\end{array}$ & $\begin{array}{l}\text { AdvanSure } \\
\text { RV-plus } \\
\text { real-time } \\
\text { RT-PCR }\end{array}$ & $\begin{array}{l}\text { AdvanSure } \\
\text { RV real-time } \\
\text { RT-PCR }\end{array}$ & $\begin{array}{l}\text { AdvanSure } \\
\text { RV-plus } \\
\text { real-time } \\
\text { RT-PCR }\end{array}$ & $\begin{array}{l}\text { AdvanSure } \\
\text { RV real-time } \\
\text { RT-PCR }\end{array}$ \\
\hline Adeno & 11 & $11(100)$ & $10(90.9)$ & $5(5.8)$ & $7(8.1)$ & $4(4.6)$ & $2(2.3)$ & $2(2.3)$ & $1(1.2)$ \\
\hline $229 \mathrm{E}$ & 2 & $2(100)$ & & & & $1(1.2)$ & & $1(1.2)$ & \\
\hline $\mathrm{BoV}$ & 11 & $11(100)$ & $10(90.9)$ & $6(5.8)$ & $7(8.1)$ & $2(2.3)$ & $2(2.3)$ & $3(3.5)$ & $1(1.2)$ \\
\hline ENT & 5 & $5(100)$ & & & & $2(2.3)$ & & $3(3.5)$ & \\
\hline INFA & 7 & $7(100)$ & $7(100)$ & $7(8.1)$ & $7(8.1)$ & & & & \\
\hline MPV & 9 & $9(100)$ & 8 (88.9) & $8(9.2)$ & $8(9.2)$ & $1(1.2)$ & & & \\
\hline OC43 & 7 & $6(85.7)$ & 7 (100) & $5(5.8)$ & $7(8.1)$ & $1(1.2)$ & & & \\
\hline PIV1 & 2 & $2(100)$ & $2(100)$ & $2(2.3)$ & $2(2.3)$ & & & & \\
\hline PIV3 & 9 & $9(100)$ & $9(100)$ & $4(4.6)$ & $4(4.6)$ & $4(4.6)$ & $5(5.8)$ & $1(1.2)$ & \\
\hline Rhino & 16 & $16(100)$ & $15(93.8)$ & $5(5.8)$ & $7(8.1)$ & $7(8.1)$ & $7(8.1)$ & $4(4.6)$ & $1(1.2)$ \\
\hline RSVA & 7 & $7(100)$ & $6(85.7)$ & $6(6.9)$ & $6(6.9)$ & $1(1.2)$ & & & \\
\hline RSVB & 1 & $1(100)$ & $1(100)$ & $1(1.2)$ & $1(1.2)$ & & & & \\
\hline Total & 87 & $86(98.9)$ & $75(86.2)$ & $49(56.3)$ & $56(64.4)$ & $23(26.4)$ & $16(18.4)$ & $14(16.1)$ & $3(3.5)$ \\
\hline
\end{tabular}

Abbreviations: See Table 1.

Table 3. Detection difference in co-infections clinical nasopharyngeal swab specimens

\begin{tabular}{cll}
\hline Number & \multicolumn{1}{c}{ AdvanSure RV-plus real-time RT-PCR } & AdvanSure RV real-time RT-PCR \\
\hline 1 & Adenovirus, Rhinovirus & Adenovirus \\
2 & Bocavirus, Coronavirus & Coronavirus \\
3 & Rhinovirus, Enterovirus & Rhinovirus \\
4 & Adenovirus, Respiratory syncytial virus A, Coronavirus & Adenovirus \\
5 & Bocavirus, Rhinovirus, Enterovirus & Bocavirus, Rhinovirus \\
6 & Parainflenza Virus 3, PIV3, Coronavirus OC43 & Parainflenza Virus 3, PIV3 \\
7 & Bocavirus, Adenovirus & Bocavirus \\
8 & Bocavirus, Rhinovirus, Enterovirus & Bocavirus, Rhinovirus \\
9 & Parainflenza Virus 3, PIV3, Rhinovirus, Enterovirus & Parainflenza Virus 3, PIV3, Rhinovirus \\
10 & Rhinovirus, Enterovirus & Rhinovirus
\end{tabular}

increases the risk of antibiotic side-effects, emergence of antimicrobial resistance, and cost of unnecessary care [19]. There are currently multiple respiratory viruses that contribute to the burden of respiratory viral diseases. These viruses can affect people of all ages, including infants, children, young adults, adults, elderly people, and immunocompromised people.

Moreover, early diagnosis allows physicians to create an appropriate clinical management plan. Timely diagnosis has been proven to prevent inappropriate use of antibiotics and help in public health surveillance measures. Molecular technology demonstrates several benefits including quick results with higher sensitivity and specificity. The rapidity of molecular techniques allows them to be the best tools for surveillance during epidemics [20-23]. Evaluation of AdvanSure RV-plus real-time RT-PCR kit (LG Life Sciences) and AdvanSure RV real-time RT-PCR kit (LG Life Sciences) in respiratory nasopharyngeal specimens showed $96.9 \%$ sensitivity, comparable to the sensitivity between AdvanSure RV real-time RT-PCR (LG Life Sciences) with other PCR kits [17]. Negative percent agreement, positive percent agreement, kappa value, and $P$ value for the two assays were $90.0 \%, 98.4 \%$, and 0.9 , respectively ( $P$ $<0.001)$. These agreements are comparable to findings from others studies [24-26]. The overall agreement was 96.4\%, which is high agreement as reported in other studies comparing 
AdvanSure RV real-time RT-PCR (LG Life Sciences) with other kits [26]. The $98.9 \%$ the high positive rate in the new test kit when comparing the positive rate between the new and old test kits was significantly affected by the possible detection of enterovirus and coronavirus 229E $(P$ value $<0.001)$ and there was no statistical significant difference in the detection of each other virus.

To the best of our knowledge, there is no previous study that compares LG AdvanSure RV real-time RT-PCR (LG Life Sciences) and the new AdvanSure RV-plus real-time RT-PCR kit (LG Life Sciences) in nasopharyngeal swab samples. Evaluation of the AdvanSure RV-plus real-time RT-PCR assay (LG Life Sciences) against AdvanSure RV real-time RT-PCR (LG Life Sciences) in respiratory nasopharyngeal specimens resulted in $96.9 \%$ sensitivity and $94.7 \%$ specificity. AdvanSure RV real-time RT-PCR (LG Life Sciences) detected 75 (86.2\%) positive results, and AdvanSure RV-plus real-time RT-PCR (LG Life Sciences) detected 86 (98.9\%) positive results. Other studies have compared AdvanSure RV real-time RT-PCR (LG Life Sciences) with other PCR kits and showed the slightly higher positive detection of rate for AdvanSure RV real-time RT-PCR (LG Life Sciences). While other kits showed much more capacity for positive detection of respiratory viruses, the new AdvanSure RV-plus real-time RT-PCR kit (LG Life Sciences) showed higher positive detection rate than AdvanSure RV real-time RT-PCR (LG Life Sciences) [24,26,27]. AdvanSure RV real-time RT-PCR (LG Life Sciences) demonstrated good performance capacity in multiple virus-infected nasopharyngeal specimens. AdvanSure RV-plus real-time RT-PCR (LG Life Sciences) showed good performance to detect multiple viruses in clinical specimens (Table 2).

AdvanSure RV-plus real-time RT-PCR (LG Life Sciences) detected $42.5 \%(n=37)$ in 16 co-infected clinical samples, while AdvanSure RV real-time RT-PCR (LG Life Sciences) detected $21.8 \%(n=19)$ in 9 clinical samples with co-infection with multiple viruses, more details were described in Table 3. However, there are still contradictory reports on the impact of being infected by multiple viruses; evidence from published studies has shown an association between co-infection with multiple viruses and the severity of clinical manifestations [17]. The AdvanSure RV-plus real-time RT-PCR (LG Life Sciences) was able to detect coronavirus E229 which was missed by the AdvanSure RV real-time RT-PCR (LG Life Sciences) and additionally detect ENT. The human coronavirus 229E usually causes mild upper respiratory infections in immunocompetent adults, but may lead to severe complications or mortality in immunocompromised individuals [28]. In this study, human enterovirus detected in coinfections samples together with rhinovirus (ENT/HRV). The similar results were found in other studies, ENT/HRV have been identified as the leading cause acute asthma exacerbations, bronchiolitis, and viral pneumonia. Although some studies were unable to describe the clinical severity associated to ENT/HRV, the study conducted in younger children admitted in hospital for bronchiolitis reported the severity; other studies reported that bronchiolitis due to ENT/HRV resulted in less severe disease compared to Respiratory syncytial virus A and B bronchiolitis among infants [29].

Limitation of this study was the nasopharyngeal specimens were tested by AdvanSure RV real-time RT-PCR (LG Life Sciences) after the samples were stored at $-70^{\circ} \mathrm{C}$. They were then tested by AdvanSure RV-plus real-time RT-PCR (LG Life Sciences). Since the experiments were not carried out at the same time, there is a possibility of false positives due to contamination.

Overall, the performance of LG AdvanSure RV real-time RT-PCR (LG Life Sciences) and the new AdvanSure RV-plus real-time RT-PCR kit (LG Life Sciences) showed strong agreement. AdvanSure RV-plus real-time RT-PCR (LG Life Sciences) showed a better detection rate with high sensitivity and specificity. AdvanSure RV-plus real-time RT-PCR kit (LG Life Sciences) is a useful tool for respiratory virus diagnosis in clinical settings.

\section{REFERENCES}

1. Moesker FM, van Kampen JJ, van Rossum AM, de Hoog M, Koopmans MP, Osterhaus AD, et al. Viruses as sole causative agents of severe acute respiratory tract infections in children. PLoS One 2016;11:e0150776.

2. Tregoning JS, Schwarze J. Respiratory viral infections in infants: causes, clinical symptoms, virology, and immunology. Clin Microbiol Rev 2010;23:74-98.

3. Legand A, Briand S, Shindo N, Brooks WA, de Jong MD, Farrar $\mathrm{J}$, et al. Addressing the public health burden of respiratory viruses: the Battle against Respiratory Viruses $(\mathrm{BRaVe})$ initiative. Future Virol 2013;8:953-68.

4. Pinky L and Dobrovolny HM. Coinfections of the respiratory tract: viral competition for resources. PLoS One 2016;11:e0155589.

5. Mehta S, Shin H, Burnett R, North T, Cohen AJ. Ambient particulate air pollution and acute lower respiratory infections: a systematic review and implications for estimating the global burden of disease. Air Qual Atmos Health 2013;6:69-83.

6. Salez N, Vabret A, Leruez-Ville M, Andreoletti L, Carrat F, Renois F, et al. Evaluation of four commercial multiplex molecular tests for the diagnosis of acute respiratory infections. 
PLoS One 2015;10:e130378.

7. Peaper DR and Landry ML. Rapid diagnosis of influenza: state of the art. Clin Lab Med 2014;34:365-85.

8. Hodinka RL and Kaiser L. Point-counterpoint: is the era of viral culture over in the clinical microbiology laboratory? J Clin Microbiol 2013;51:2-8.

9. Basile K, Kok J, Dwyer DE. Point-of-care diagnostics for respiratory viral infections. Expert Rev Mol Diagn 2018;18:75-83.

10. Souf S. Recent advances in diagnostic testing for viral infections. Biosci Horiz 2016;9:hwz010.

11. Loeffelholz MJ. Rapid diagnosis of viral infections. Lab Med 2002;33:283-6.

12. Gowin E, Bartkowska-Śniatkowska A, Jończyk-Potoczna K, Wysocka-Leszczyńska J, Bobkowski W, Fichna P, et al. Assessment of the usefulness of multiplex real-time PCR tests in the diagnostic and therapeutic process of pneumonia in hospitalized children: a single-center experience. Biomed Res Int 2017;2017:8037963.

13. Huang HS, Tsai CL, Chang J, Hsu TC, Lin S, Lee CC. Multiplex PCR system for the rapid diagnosis of respiratory virus infection: systematic review and meta-analysis. Clin Microbiol Infect 2018;24:1055-63.

14. Kralik $P$ and Ricchi M. A basic guide to real time PCR in microbial diagnostics: definitions, parameters, and everything. Front Microbiol 2017;8:108.

15. Krause JC, Panning M, Hengel H, Henneke P. The role of multiplex PCR in respiratory tract infections in children. Dtsch Arztebl Int 2014;111:639-45.

16. To KK, Lu L, Yip CC, Poon RW, Fung AM, Cheng A, et al. Additional molecular testing of saliva specimens improves the detection of respiratory viruses. Emerg Microbes Infect 2017;6:e49.

17. Cho CH, Lee CK, Nam MH, Yoon SY, Lim CS, Cho Y, et al. Evaluation of the AdvanSure ${ }^{\mathrm{TM}}$ real-time RT-PCR compared with culture and Seeplex RV15 for simultaneous detection of respiratory viruses. Diagn Microbiol Infect Dis 2014;79:14-8.

18. Kuan CS, Yew SM, Hooi PS, Lee LM, Ng KP. Detection of respiratory viruses from ARTI patients by xTAG RVP Fast v2 assay and conventional methods. Malays J Med Sci 2017;24: $33-43$.
19. Piltcher OB, Kosugi EM, Sakano E, Mion O, Testa JRG, Romano FR, et al. How to avoid the inappropriate use of antibiotics in upper respiratory tract infections? A position statement from an expert panel. Braz J Otorhinolaryngol 2018;84:265-79.

20. Marshall DJ, Reisdorf E, Harms G, Beaty E, Moser MJ, Lee WM, et al. Evaluation of a multiplexed PCR assay for detection of respiratory viral pathogens in a public health laboratory setting. $\mathrm{J}$ Clin Microbiol 2007;45:3875-82.

21. Kim H, Hur M, Moon HW, Yun YM, Cho HC. Comparison of two multiplex PCR assays for the detection of respiratory viral infections. Clin Respir J 2014;8:391-6.

22. Bibby DF, McElarney I, Breuer J, Clark DA. Comparative evaluation of the Seegene Seeplex RV15 and real-time PCR for respiratory virus detection. J Med Virol 2011;83:1469-75.

23. Christaki E. New technologies in predicting, preventing and controlling emerging infectious diseases. Virulence 2015;6:558-65.

24. Jung YJ, Kwon HJ, Huh HJ, Ki CS, Lee NY, Kim JW. Comparison of the AdvanSure ${ }^{\mathrm{TM}}$ real-time RT-PCR and Seeplex ${ }^{\circledR}$ RV12 ACE assay for the detection of respiratory viruses. J Virol Methods 2015;224:42-6.

25. Boivin G, Côté S, Déry P, De Serres G, Bergeron MG. Multiplex real-time PCR assay for detection of influenza and human respiratory syncytial viruses. J Clin Microbiol 2004;42:45-51.

26. Yun SG, Kim MY, Choi JM, Lee CK, Lim CS, Cho Y, et al. Comparison of three multiplex PCR assays for detection of respiratory viruses: Anyplex II RV16, AdvanSure RV, and Real-Q RV. J Clin Lab Anal 2018. doi: 10.1002/jcla.22230.

27. Huh HJ, Kim JY, Kwon HJ, Yun SA, Lee MK, Lee NY, et al. Performance evaluation of Allplex respiratory panels 1, 2, and 3 for detection of respiratory viruses and influenza A virus subtypes. J Clin Microbiol 2017;55:479-84.

28. Yan L, Meng B, Xiang J, Wilson IA, Yang B. Crystal structure of the post-fusion core of the Human coronavirus 229E spike protein at $1.86 \AA$ resolution. Acta Crystallogr D Struct Biol 2018;74:841-51.

29. Asner SA, Petrich A, Hamid JS, Mertz D, Richardson SE, Smieja M. Clinical severity of rhinovirus/enterovirus compared to other respiratory viruses in children. Influenza Other Respir Viruses 2014;8:436-42. 
$=$ 국문초록=

\title{
비인두 면봉 검체에서 다중실시간중합효소연쇄반응 키트의 호흡기 바이러스 검출능 비교
}

\author{
${ }^{1}$ 연세대학교 의과대학 진단검사의학교실 및 세균내성연구소, \\ ${ }^{2}$ 연세대학교 보건대학원 글로벌 보건안보학과, ${ }^{3}$ 르완다 룰리 병원 응급의료과 \\ Jean Damascene Uwizeyimana ${ }^{1,2,3}$, 김민경 ${ }^{1}$, 김대원 ${ }^{1}$, 변정현 $^{1}$, 용동은
}

배경: 호흡기 감염은 공중 위생을 위협하는 주된 요인이므로 감염 원인을 검출, 규명하는 것은 신속하고 적절한 항균 요법 시작과 2 차 감염 예방에 도움을 준다. 본 연구의 목표는 비인두 면봉 검체에서 호흡기 바이러스를 검출하는 2 종의 상품화된 다중실시간중합효소연쇄반응 키트의 검출능을 비교하는 것이다.

방법: 2017년 9월에서 10월에, 총 84개의 비인두 잔여 검체를 3차 의료기관 환자들로부터 $3 \mathrm{~mL}$ universal transport medium 운반 배지(COPAN Diagnostics, USA)를 이용하여 수집하였다. 키트 간 검출능 비교를 위해 LG AdvanSure RV real-time RT-PCR (LG Life Sciences, Korea) 키트로 얻은 64개 양성과 20개 음성 검체를 최근 개발된 LG AdvanSure RV-plus real-time RT-PCR 키트로 재검하였다.

결과: 서로 다른 두 키트 간 양성 및 음성 일치도에 대한 통계적인 분석법으로 새로 소개된 AdvanSure RV-plus real-time RT-PCR 키트 및 AdvanSure RV real-time RT-PCR 간에 평가하였다. 전반적인 일치도는 96.4\%였고, $98.4 \%$ 의 양성 일치도 와 $90.0 \%$ 의 음성 일치도를 보였다. AdvanSure RV-plus real-time RT-PCR에서 평가된 민감도와 특이도는 각각 $96.9 \%$ 와 94.7\%였고, kappa value는 $0.9(P<0.001)$ 였다.

결론: LG AdvanSure RV real-time RT-PCR과 새로운 AdvanSure RV-plus real-time RT-PCR 키트의 성능은 강한 일치도를 보였고, 새로 개발된 AdvanSure RV-plus real-time RT-PCR이 더 좋은 검출률을 보였다. AdvanSure RV-plus real-time RT-PCR 키트는 임상미생물 검사실에서 호흡기 바이러스 감염 진단을 위한 유용한 수단으로 고려할 수 있을 것으로 판 단된다. [Ann Clin Microbiol 2019;22:35-41]

교신저자 : 용동은, 03722, 서울시 서대문구 연세로 50-1

연세대학교 의과대학 진단검사의학교실 및 세균내성연구소

Tel: 02-2228-2442, Fax: 02-364-1583

E-mail: deyong@yuhs.ac 